\title{
CHLAMYDOSPORE FORMATION BY Paracoccidioides brasiliensis MYCELIAL FORM
}

\section{SUMMARY}

To investigate the role of some adverse environmental conditions in chlamy dospore formation by the mycelial form of $\mathbf{P}$. brasiliensis, we cultured four $\mathbf{P}$. brasiliensis isolates $(18, \mathrm{Bt} 4,1183, \mathrm{~Pb} 9)$ at $25^{\circ} \mathrm{C}$ within solid agar medium either rich or poor in nutrients. Isolates 18 and 1183 were also cultured under anaerobiosis in a nitrogen atmosphere. Isolate 18 produced great number of terminal and intercalary chlamydospore after 7-10 days of culture in a medium poor in nutrients $(2 \%$ agar with $0.1 \%$ dextrose and polypepton).

The three other isolates also produced chlamydospores under the same conditions, but in lower numbers. Chlamydospore production by isolate 18 was abolished when the fungus was cultured in two agar media rich in nutrients (brain heart infusion and potato dextrose agar). Anaerobic incubation of isolate 18 under an atmosphere of N2 showed small mycelial outgrowth with numerous chlamydospores. At the electron microscopical level, the chlamydospores showed one or various nuclei and numerous mitochondria, indicating great potential for further development. Accordingly, chlamydospores produced multiple budding after only $24 \mathrm{~h}$ incubation at $35^{\circ} \mathrm{C}$. The results demonstrate that under adverse environmental conditions $P$. brasiliensis mycelial form produces chlamydospores within a short period of time.

KEY WORDS: Chlamydospore; Paracoccidioides brasiliensis.

\section{INTRODUCTION}

Paracoccidioides brasiliensis, the causative agent of paracoccidioidomycosis, is a thermally dimorphic fungus producing a mycelial form at room temperature and yeast form at $37^{\circ} \mathrm{C}$. In the mycelial phase, it may give rise to either few nonspecific sporulating structures or characte ristic spores ${ }^{19,} 20$.

The exact mechanism of infection is not known, because of uncertainty about the natural habitat of the fungus. Most authors believe that infection is acquired by inhalation, and that co nidia may be the infectious propagules ${ }^{8 .}{ }^{20}$. Re cently the substrate and cultural requirements were met to the production of various types of P. brasiliensis conidia. Using culture media poor in nutrients and incubation time ranging from 3 to 6 weeks, RESTREPO and co-workers descri bed the development of arthroconidia, single celled conidia and aleuroconidia ${ }^{3.22 .23}$. The same

(1) Department of Pathology, Botucatu Medical School, Sāo Paulo State University, Botucatu, São Paulo, Brazil (2) Research Center of Pathogenic Fungi \& Microbial Toxicoses, Chiba University, 1 8 1, Inohana, Chiba 280, Japan Address for correspondence: Marcello Franco, M.D., Departamento de Patologia, Faculdade de Medicina UNESP. CEP 18610 Botucatu, Săo Paulo, SP, Brazil. 
FRANCO, M.: SANO, A.; KERA, K.; NISHIMURA, K.; TAKEO, K. \& MIYAJI, M. - Chlamydospore formation by Paracoccidioides brasiliensis mycelial form. Rev. Inst. Med. trop. S. Paulo, 31(3): 151 - 157, 1989.

authors were able to separate and quantitate the arthroconidia and successfully infect mice by intranasal instillation, producing active disease in healthy animals ${ }^{13}$. Despite the fact that chlamydospore formation has long been described at early stages in the mycelial grow th of P. brasiliensis ${ }^{4}$.5, 7. 17, 18. 19. 24, and that chlamydospores seem to be the transitional form in the mycelial to yeast conversion ${ }^{4.16}$, little attention has been given to its optimal cultural conditions and potential infectivity. CARBONELL \& RODRI GUEZ $Z^{4}$ gave indication that chlamydospore for mation in P. brasiliensis mycelial form occurred under adverse condition, namely poor oxygenation: using slant cultures, the authors observed an outermost layer, outside the culture medium, consisting of slender hyphae without spores, and a middle layer, possibly under low oxygen atmosphere, with abundant in tercalary and terminal chlamydospores.

While attempting to grow $\mathbf{P}$. brasiliensis my. celia inside the agar of a culture medium poor in nutrients ${ }^{16}$, we observed that within a short period of time, the mycelial growth produced great number of intercalary and terminal chlamydospores. We hypothesized that the resistant cells were being formed subsequent to starvation and low oxigen content. The present investigation was aimed at studying chlamydospore formation among different isolates of $\mathbf{P}$. brasiliensis in media with different nutritional content and different levels of 02 atmosphere.

\section{MATERIAL AND METHODS}

1. Chlamydospore formation by P. brasiliensis isolates - Four isolates were examined. They were selected at random from a collection of stock cultures obtained worldwide, namely strain 18 (Department of Microbiology, São Paulo State School of Medicine. Brazil), strain Bt4 (Department of Pathology, Botucatu Medical School, Sâo Paulo, Brazil), strain Pb9 (Instituto Venezolano de Investigaciones Cientificas, Caracas, Venezuela) and strain 1183 (Centers for Disease Control, Atlanta Georgia, USA). Fresh transfers were done to slants of brain heart infusion agar (Difeo, Detroit, Michigan), supplemented with $1 \%$ dextrose, and incubated at $35^{\circ} \mathrm{C}$ for 5 to 7 days. the growth was harvested in sterile phosphate buffered saline (PBS; pH $7.4 ; 1 / 15 \mathrm{M}$ ) by carefully scraping the yeast mat with a pipet te. The suspension was further homogenized by vortexing and then filtered through cotton gauze. The inoculum was adjusted to a concentration of $10^{5}$ to $10^{6}$ fungal cells $/ \mathrm{ml}$. Solid cultures in $90 \times 20 \mathrm{~mm}$ petri dishes were then set up in duplicates: one $\mathrm{ml}$ of the yeast cell suspension was carefully mixed with $25 \mathrm{ml}$ of $2 \%$ agar (immunodiffusion agar for immunoelectrophoresis, Oxoid, England), with $0.1 \%$ polypepton (Wako Pu re Chemicals Ind., Osaka, Japan) and $0.1 \%$ anhy drous dextrose (Wako) $\left(0.1 \%\right.$ IDAgar), at $40-43^{\circ} \mathrm{C}$. The cultures were prepared in duplicate for each strain. After solidification of the agar, the plates were incubated at $25^{\circ} \mathrm{C}$ for 5,7 and 10 days. At day 10 , the plates were incubated at $35^{\circ} \mathrm{C}$ for 5 days.

For direct examination of the cultures, a small sample of the medium was cut with a razor blade and placed on a microslide together with a drop of lacto-phenol cotton blue; a cover slip was then laid over it, carefully pressed, and the specimen was observed directly under a light microscope. For each dish, 2 slides were prepared The numbers of chlamydospores present in 10 to 15 high power fields (HPF; 400X) of each slide selected at random were counted in a blind way. For histological examination, similar samples from each dish were formalin fixed, paraffin em. bedded, cut in $15 \mu \mathrm{m}$ sections and stained with PAS, according to routine procedures.

2. Chlamydospore formation in poor and rich culture media - Isolate 18 and three different agar media were used, namely $0.1 \%$ IDAgar, brain heart infusion and potato dextrose agar (Difco). In all media, the agar concentration was $2 \%$. One $\mathrm{ml}$ of yeast cell suspension was mixed with $25 \mathrm{ml}$ of each melted medium (approx $40^{\circ} \mathrm{C}$ ) and cultured in duplicates at $25^{\circ} \mathrm{C}$ for 10 days as described above. For the microscopical observation, lactophenol cotton blue preparations were made with a loopful of each plate; the numbers of chlamydospores were counted as described above.

\section{Chlamydospore formation in anaerobic} condition - The technique employed for culturing isolates 18 and 1183 of $P$. brasiliensis was the same described for the previous experiments. The culture medium used was $0.1 \%$ IDAgar. Cultures were kept at $25^{\circ} \mathrm{C}$ for 7 clays under anaerobic conditions in a nitrogen atmosphere 
FRANCO, M; SANO, A.; KERA, K.; NISHIMURA, K.; TAKEO, K. \& MIYAJI, M. - Chlamydospore formation by Paracoccidioides brasiliensis mycelial form. Rev. Inst. Med. trop. S. Paulo, 31(3): 151-157, 1989.

produced as follows. A BBLGas Pak plastic jar (Becton, Dickinson Co., Cockeysville, USA) was placed inside a vinyl-isolated chamber for hazardous experiments, containing a sealed entrance and two vinyl-isolated windows for handling. A continuous flow of pure nitrogen (Nihon Sanso Co. Ltd, Tokyo, Japan) was then produced inside the chamber and the plastic jar. Afterwards the petri dishes containing the solid cultures were rapidly introduced inside the jar together with steel wool coated with copper for elimination of the residual oxygen. The jar was then sealed.

For coating the steel wool, approximately $50 \mathrm{~g}$ steel wool were dipped twice into $300 \mathrm{ml}$ of a $1 \%$ cupric sulfate solution until decolouration of the solution. The copper-coated steel wool was squeezed to remove the excess of water and placed into the plastic jar. The copper in the surface of the wool reacts with the residual oxigen with the subsequent production of copper oxide. To ensure the presence of a atmosphere of $\mathrm{N} 2$ inside the jar, a balloon filled with the gas was connected to the jar through the lid and clamped when no further shrinkage of the balloon was observed.

For the microscopic examination, the proce dures were the same as used in the previous ex periments.

4. Electron microscopic morphology of chlamydospores - Isolate 18 was cultured as described above in $0.1 \%$ IDAgar at $25^{\circ} \mathrm{C}$ for 10 days. Afterwards, samples from the solid culture me dium were fixed in $2.5 \%$ glutaraldehyde in Hank's solution ( $\mathrm{pH} 7.2-7.4$ ) at $4^{\circ} \mathrm{C}$ for 4 days, post-fixed in $1 \%$ osmium tetroxide in Hank's solution for $2 \mathrm{~h}$, dehydrated in a graded series of ethanol and embedded in Epon-812 resin.

Ultrathin sections were doubly stained with $2 \%$ uranyl acetate in $60 \%$ ethanol, and lead citrate. They were examined with a Hitachi $\mathrm{H}-700 \mathrm{H}$ electron microscope at $100 \mathrm{kV}$.

\section{RESULTS}

We defined chlamydospores, as proposed by AINSWORTH ${ }^{10}$, as thick-walled nondeciduous intercalary and terminal asexual spores formed by the rounding up of preexisting cells.
The numbers of chlamydospores produced by the four $\mathbf{P}$. brasiliensis isolates, expressed by the median of spores present in $60 \mathrm{HPF}(15$ HPF in each cotton blue preparation: 2 microslides per plate, 2 plates per isolate) at day 10 , are shown in Fig. 1. Isolate 18 produced a great number of both intercalary (Fig. 2A, B, C) and terminal (Fig. 2A, B, D, E, F) chlamydospores after 10 days of culture at $25^{\circ} \mathrm{C}$. As the spores were counted at randomly selected microscopical fields, the number of spores per HPF shown by isolate 18 varied from 9 to 49 . However, the process of sporulation was homogeneous throughout the fungal colonies inside the solid culture medium (Fig. 3a). The chlamydospores ranged in diameter from 5 to $20 \mu \mathrm{m}$ and presented a thick cell wall (Fig. 2). In the cytoplasm, there were intensely blue-stained areas ( $F$ ig. 2). At day 10 , when the plates containing numerous spores

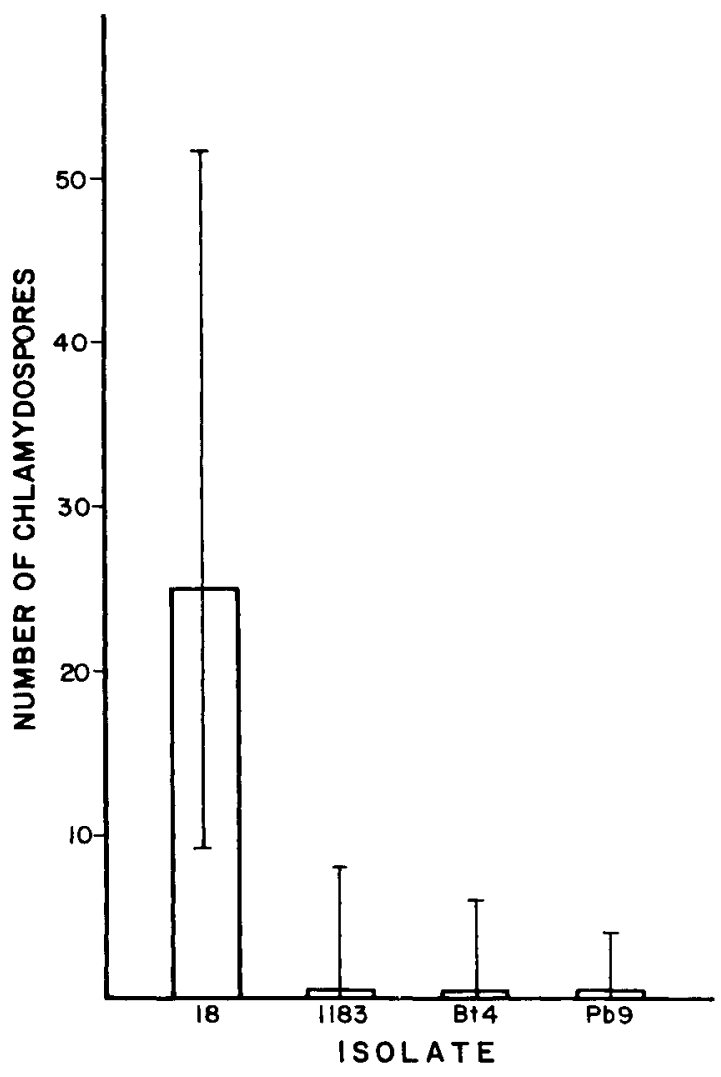

Fig. 1-Chlamydospore formation by four P. brasiliensis isolates cultured in $2 \%$ agar with $0.1 \%$ polypepton and dextrose for 10 days at $25^{\circ} \mathrm{C}$. Columns are the medians of the numbers of spores in 60 high power fields counted in 4 microslides (2 slides per plate; 2 plates per isolate). Bars represent the range between the highest and lowest numbers. 
FRANCO, M.; SANO, A.; KERA, K.; NISHIMURA, K.: TAKEO, K. \& MIYAJI, M. - Chlamydospore formation by Paracoccidioides brasiliensis mycelial form. Rev. Inst. Med. trop. S. Paulo, 31(3): 151 157, 1989.

were incubated at $35^{\circ} \mathrm{C}$, chlamydospores already showed multiple budding after 24 hours (Fig. 2 G. H, I). Chlamydospore formation by isolates $1183, \mathrm{Bt} 4$ and $\mathrm{Pb} 9$ was significantly less frequent than by isolate 18 (Student's t test; $\mathrm{p}<0.001$ ).

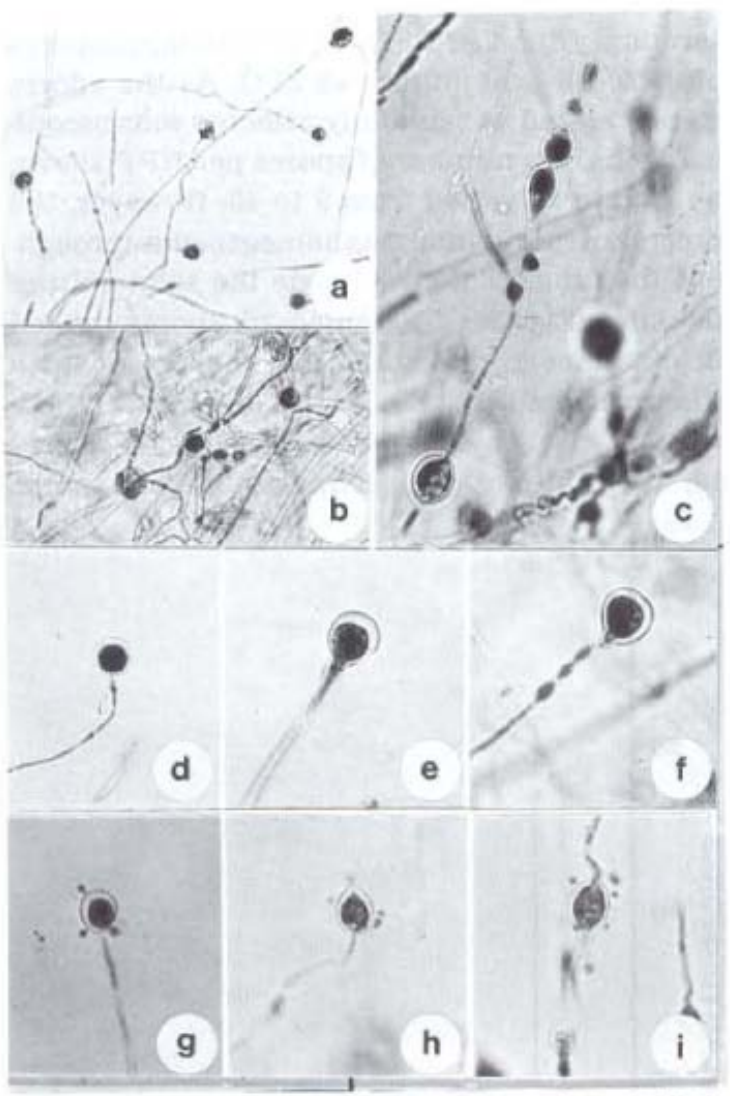

Fig. 2 - Terminal (A, B, D, E, F) and intercalary (A, B, C) chlamydospores. Note the thick cell wall and deeply stained matrix inside. Irregular swellings fimmature chlamydospores are less than $5 \mu \mathrm{m}$ in diameter and show normal cell wall (A $B$, C). Chlamydospores with multiple budding after 1 day at $35^{\circ} \mathrm{C}$ (G, H, I) (cotton blue preparations; A, C $=200 x, B$ $I=400 x)$.

Sporulation by isolate 18 was already observed at day 7 , although it was significantly less frequent than at day 10 , as demonstrated by the median counts of 4 and 25 spores in $60 \mathrm{HPF}$. respectively (Student's t test; $\mathrm{p}<\mathbf{0 . 0 0 1}$ ). No chlamydospore formation was detected at day 5 .

In addition to typical chlamydospores, there were numerous segmentary swellings with dia meter less than $5 \mu \mathrm{m}$ and thin cell wall (Fig. $2 \mathrm{~A}, \mathrm{~B}, \mathrm{C})$; these structures were interpreted as immature chlamydospores.
The histological examination of the solid culture medium of both mature and immature chlamydospores showed similar findings to those described above (Fig. 3 )

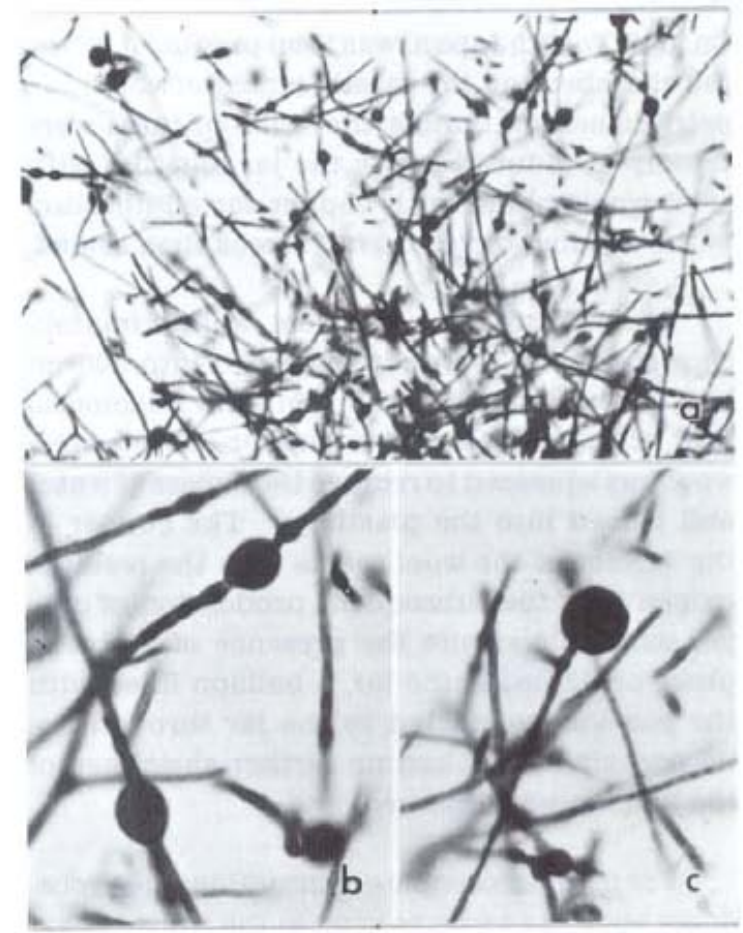

Fig. 3 - Sporulation by $\mathbf{P}$. brasiliensis isolate 18, cultured in $2 \%$ agar with $0.1 \%$ polypepton and dextrose for 10 days at $25^{\circ} \mathrm{C}$. Note terminal $(\mathrm{C})$ and intercalary $(\mathrm{B})$ chlamydospores with thick cell wall and deeply stained material inside (PAS $15 \mu \mathrm{m}$ sections of parafñn embedded solid culture medium. $A=200 x, B, C=400 x$

Sporulation by isolate 18 showed a positive correlation with the poor nutritional content of the culture medium. The medium poor in $\mathrm{nu}$ trients $(0.1 \%$ ID Agar) yielded a greater number of spores (median of spores per $\mathrm{HPF}=22$; lowest count $=14$; highest count $=35$ ). The two rich media (BHI and PDA) did not induce chlamydospore formation.

Anaerobic incubation of isolate 18 and 1183 under an atmosphere of $\mathrm{N} 2$ resulted in a limited outgrowth as observed grossly by the small size of the colonies in the solid medium. Cotton blue preparations of the cultures of both isolates re. vealed hyphal growth with chlamydospore formation (Fig. 4). 
FRANCO, M.; SANO, A.; KERA, K.; NISHIMURA, K.; TAKEO, K. \& MIYAJI, M. - Chlamydospore formation by Paracoccidioides brasiliensis mycelial form. Rev. Inst. Med. trop. S. Paulo, 31(3): 151-157, 1989

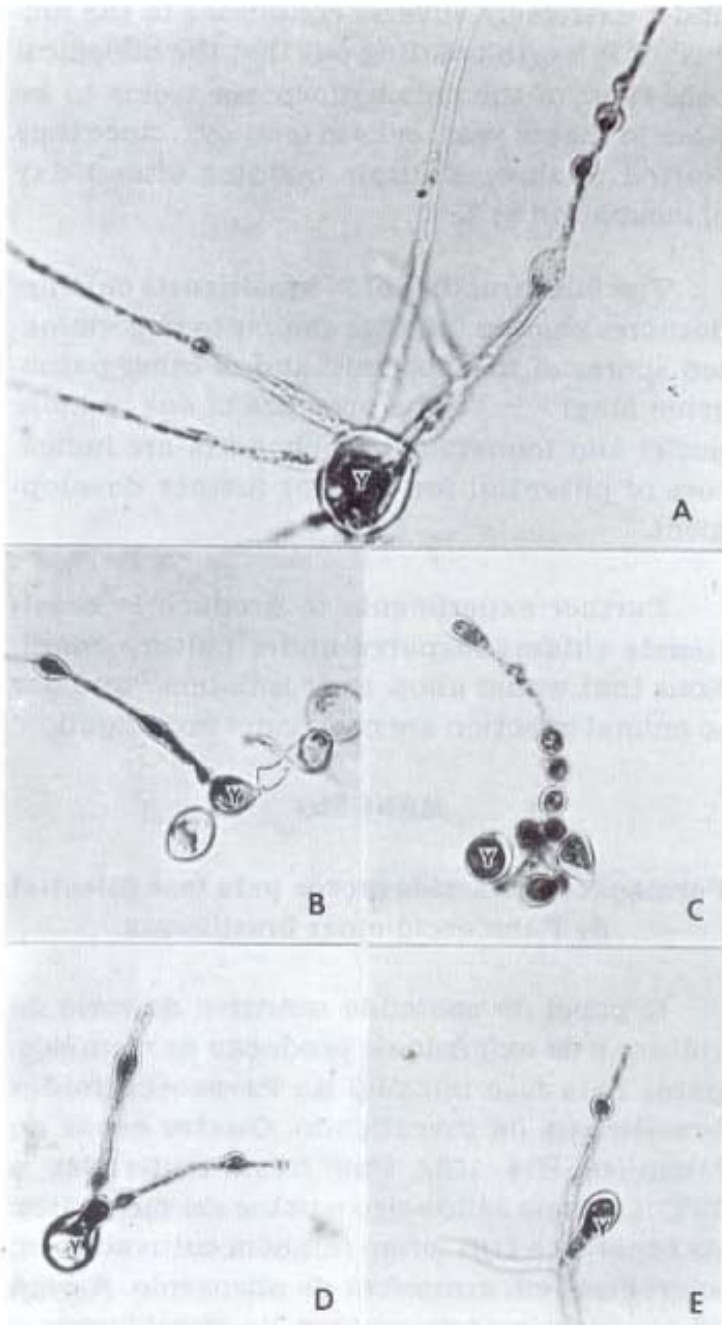

Fig. 4 - Anaerobic incubation of $\mathbf{P}$, brasiliensis under an atmosphere of nitrogen. Yeast cells (Y) from the inoculum show hyphal growth with intercalary (A, B, D, E), and terminal chlamydospores (C, D) (cotton blue preparations; $A=200 x, B$, C. $D, E=400 x$.

The transformation process from hyphae to terminal chlamydospores of isolate 18 cultured in $0.1 \%$ IDAgar for 10 days was studied by electron microscopy. At the early stage intercalary and terminal cellular components of the hyphal form began to round up (Fig. 5). These irregular swellings or immature chlamydospores contained one or more nuclei, and showed all the organelles present in the hyphae counterpart; the cell wall had also the same morphological appearance and thickness. The fully developed spores were round structures with one or several nuclei, numerous vacuoles, lipid droplets, endoplasmic reticulum, vesicles and mitochondria. The cell wall was characteristically thick $(=260 \mathrm{~nm}$ ) and consisted of an electron-translucent inner layer and an electron-dense granular ou ter layer con tinuous with the outer layer of the suspensor cell wall.

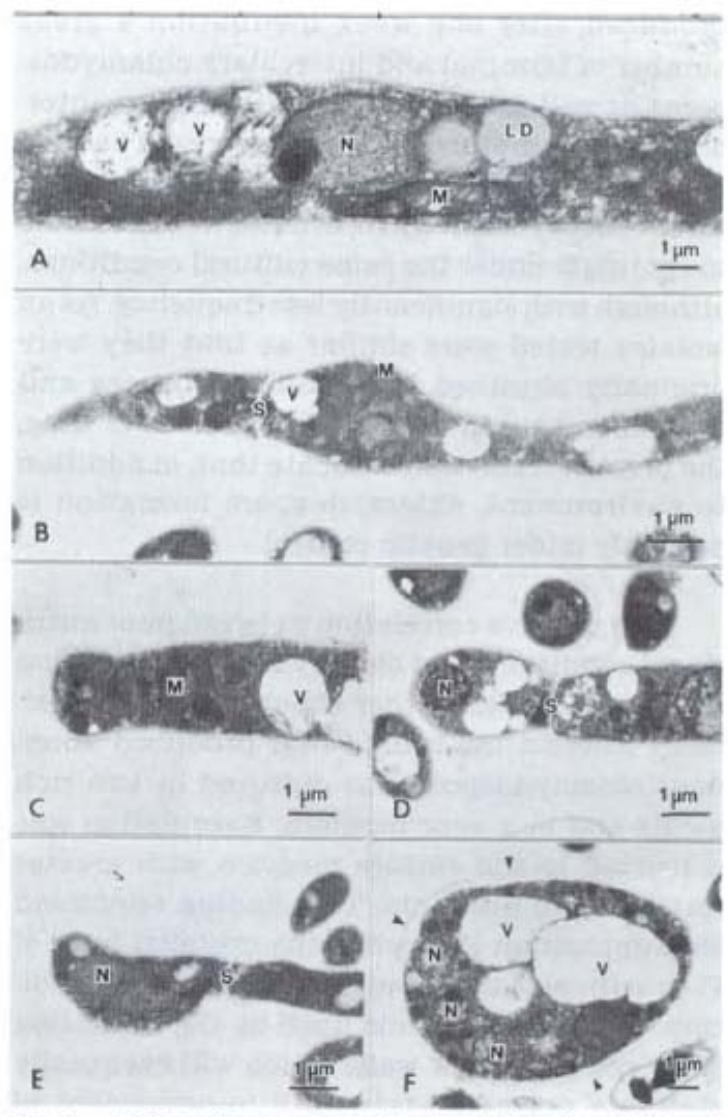

Fig. 5 - Chlamydospore formation by isolate 18 of $\mathbf{P}$. brasiliensis cultured at $25^{\circ} \mathrm{C}$ for 10 days. Irregular intercalary (B) and terminal (C, D, E) swellings (immature forms), and mature chlamydospore (F). Note septum (S), ore or more nuclei (N), mitochondria (M), vacuoles (V), lipid droplets (LD) and thick cell wall of the mature form (arrowheads) (E).

\section{DISCUSSION}

It is well known that several fungi under adverse conditions, such as starvation, exposure to membrane-aitering or enzyme-activating agents, develop units of hyphal differentiation produced by isotropic growth ${ }^{9,25}$. These resistant cells are called chlamydospores and they need dissolution of the supporting hyphae before dispersal is possible ${ }^{6,9}$. The release can be accomplished by mechanical fracture of a non-dif- 
FRANCO, M.; SANO, A.; KERA, K.: NISHIMURA, K.: TAKEO, K. \& MIYAJI, M. - Chlamydospore formation by Paracoccidioides brasiliensis mycelial form. Rev. Inst. Med. trop. S. Paulo, 31(3): 151-157, 1989.

ierentiated cell wall or by natural breaking down of the supporting hyphae through bacterial ac tion, fungal lysis and/or weathering. ${ }^{9 .}$.

Isolate 18 of $\mathbf{P}$. brasiliensis, when grown at $25^{\circ} \mathrm{C}$ inside a solid agar medium with low nutritional content and poor availability of oxygen, produced after one week incubation a great number of terminal and intercalary chlamydos pores, as well as irregular hyphal swellings, interpreted as immature chlamydospores. The phenomenon was not restricted to one isolate, since three other $\mathbf{P}$. brasiliensis isolates were also able to sporulate under the same cultural conditions, although with significantly less frequency. As all isolates tested were similar as that they were originally obtained from clinical sources and have been kept in vitro for long period of time, the present result may indicate that, in addition to environment, chlamydospore formation is probably under genetic control.

The positive correlation between poor nutritional conditions and chlam ydospore formation by isolate 18 was further checked in an experiment wherein the isolate that produced abundant chlamydospore was cultured in two rich media and in a poor medium. Sporulation was restricted to the culture medium with greater restriction of nutrients. This finding reinforced the supposition that when the mycelial form of P. brasiliensis meets adverse nutritional condition, the fungus defends itself by the formation of spores with thick walls which will eventually stay in a dormant state until improvement of the environmental conditions.

Based on our pilot experiments, we hypothe size that chlamydospore formation in $\mathbf{P}$. brasiliensis might be multifactorial depending on nutrition and on the oxygen atmosphere. Accordingly, we carried out a further experiment to analyze the phenomenon under anaerobic condition.

Like other dimorphic pathogenic fungi ${ }^{1,14}$, P. brasiliensis showed growth under anaerobiosis although in a small scale. The growing hyphae of both isolates tested rapidly presented rounding up of some cells, with the formation of chlamydospores. This finding represents further evidence for the role of these structures as asexual spores primarily involved in perenation under extremely adverse conditions to the fungus $^{9}$. It is worth pointing out that the biological behaviour of the chlamydospores seems to be close to that of yeast cells in latency ${ }^{21}$, since they started to show multiple budding after 1 day of incubation at $35^{\circ} \mathrm{C}$.

The fine structure of $\mathbf{P}$. brasiliensis chlamy dospores showed findings similar to ungermina ted spores of this species ${ }^{24}$ and of other patho genic fungi ${ }^{11}, 15,26$. The presence of one or more nuclei and numerous mitochondria are indicators of potential for prompt further develop ment.

Further experiments to produce P. brasiliensis chlamydospores under culture condi tions that would allow their isolation ${ }^{12}$ and use to animal infection are now under investigation.

\section{RESUMO}

Formação de clamidósporos pela fase micelial do Paracoccidioides brasiliensis

O papel do conteúdo nutritivo do meio de cultura e de oxigénio na produçāo de clamidósporos pela fase micelial do Paracoccidioides brasiliensis foi investigado. Quatro cepas do fungo $(18, \mathrm{Bt4}, 1183, \mathrm{~Pb} 9)$ foram cultivadas, a $25^{\circ} \mathrm{C}$, em meio sólido rico e pobre em nutrientes. As cepas 18 e 1183 foram também cultivadas em anerobiose em atmosfera de nitrogênio. A cepa 18 produziu grande número de clamidósporos terminais e intercalares após 7-10 dias de cultura em meio sólido pobre em nutrientes (agar $2 \%$, com dextrose e polipeptona $0,1 \%$ ). As outras três cepas produziram número significativamente menor de esporos. A cepa 18 não produziu clamidósporos quando cultivada em dois meios ricos em nutrientes (infusão de cérebro e coraçāo, e agar dextrose de batata). A incubação anaeróbica da cepa 18 em atmosfera de nitrogênio apre sen tou pequeno crescimento micelial com a pre sença de numerosos clamidósporos. À nivel ultraestrutural, os clamidósporos apresentaram um ou mais núcleos e numerosas mitocôndrias, indicativos de potencial para posterior desenvolvimento. Assim, os esporos produziram gemu lação múltipla 1 dia após incubaçāo a $35^{\circ} \mathrm{C}$. Os resultados demonstraram que, sob condiçōes ambientais adversas, a fase micelial do $\mathbf{P}$. brasiliensis produz clamidósporos em curto período 
FRANCO. M.: SANO. A.: KERA, K.: NISHIMURA, K.; TAKEO, K. \& MIYAJI, M. - Chlamydospore formation by Paracoccidioides brasiliensis mycelial form. Rev. Inst. Med. trop. S. Paulo, 31(3): 151-157, 1989.

de tempo. É possivel que o fungo encontre condiçóes semelhantes no solo, produzindo os esporos, que poderiam desempenhar papel na propagação da paracoccidioidomicose.

\section{ACKNOWLEDGEMENT}

Dr. Marcello Franco was a Guest-Professor at the Research Center of Pathogenic Fungi and Microbial Toxicoses, Chiba University, under the auspices of Education Ministry of Japan.

\section{REFERENCES}

1. BARTNICKI GARCIA. S. \& NICKERSON, W. J. -- Thia mine and nicotinic acid: anaerobic growth factors for $\mathbf{M u}$ cor rouxii. J. Bact., 82: 142 148. 1961.

2. BARTNICKI GARCIA, S. \& NICKERSON, W. J. - Nutri tion, growth, and morphogenesis of Mucor rouxii. J. Bact., 84: 841858,1962

3. BUSTAMANTE, B: MeEWEN, J. G.: TABARES, A. M. ARANGO, M. \& RESTREPO. A. - Characteristics of the conidia produced by the mycelial form of Paracoceidioides brasiliensis. J. med. vet. Mycol., 23: 407.414. 1985

4. CARBONELL, L. M. \& RODRIGUEZ, J. - Transforma tion of mycelial and yeast forms of Paracoccidioides brasi. liensis in cultures and in experimental inoculations. J. Bact. 90: 504 510, 1965 .

5 CARBONELL. L. M \& RODRIGUEZ. J. - Mucilial phase of Paracoccidioides brasiliensis and Blastomyces dermatitidis: an electron microsenpe stude. J. Bact., 9ls $53354: 31968$

6. CARMICHAEL, J. W. - Blastospores, aleuriospores, chla mydospores. In: KENDRICK, B., ed. - Taxonomy of fungi imperfecti. Toronto. University of Toronto Press. 1971 p. $50 \cdot 70$

7. CONANT, N. F. \& HOWELL, A. - The similarity of the fungi causing South American blastomycosis iparacocci dioidal granuloma) and North American blastomycosis (Gilchrist's disease). J. invest. Derm., 5: 353 370, 1942

8. FRANCO, M.; MONTENEGRO, M. R.: MENDES, R. P. MARQUES, S. A.; DILLON, N. L. \& MOTA, N. G. S. Paracoccidioidomycosis: a recently proposed classifica tion of its clinical forms. Rev. Soc. bras. Med. trop., 20: $129 \cdot 132,1987$

9. GRIFFITHS. D. A. - The origin, structure and function of chlamydospore in fungi.Nova Hedwigia, 25: 503-546, 1974.

10. HAWKSWORTH, D. L.: SUTTON, B. C. \& AINSWORTH B. C. - Ainsworth \& Bisby'dictionary of the fungi. Hud dersfield. England, H. Charlesworth, 1983.

11. JANSONS, V.K. \& NICKERSON. W. J. - Induction, mor phogenesis, and germination of the chlamydospores of Candida albicans. J. Bact., 104: 910.921, 1970.
12 LIU, P \& NEWTON, A - Rapid chlamydospore forma tion by Candida albicans in a buffered alkaline medium Amer. J. clin. Path., 25: 93.97, 1955

13. MCEWEN, J. G.: BEDOYA. V.: PATINO, M. M.: SALA ZAR, M. E. \& RESTREPO, A. - Experimental murine paracoccidioidomycosis induced by the inhalation of coni dia. J. med. vet. Mycol., 25: 165. 175, 1987.

14. McVEIGH, I. \& HOUSTON, W. E. - Factors affecting mycelial to yeast phase conversion and growth of the yeast phase of Histoplasma capsulatum. Mycopathologia (Den Haag), 47: 135151,1972 .

15. MILLER, S. E.; SPURLOCK, B. O. \& MICHAELS. G. E - Electron microscopy of young Candida albicans chla mydospores. J. Bact., 119: 992 999, 1974.

16. MIYAJI. M. \& NISHIMURA, K. - Experimental fungal infections. In: MIYAJI, M ed - Animals models in medical m ycology. Boca Raton, Florida, USA, CRC Press, 1987 p. 1.52 .

17. NEVES. J. A. \& BOGLIOLO, L. - Researches on the etio logical agents of the American blastomycosis. I. Morpho logy and systematic of the Lutz's disease agent. Mycopathologia (Den Haag), 5: 133 142, 1951

18. POLLAK, L. - Aleuriospores of Paracoccidioides brasiIiensis. Mycopathologia (Den Haag), 45: 217.219, 1971

19. RESTREPO, A - A reappraisal of the microscopical ap pearance of the mycelial phase of Paracoccidioides brasiliensis. Sabouraudia, 8: $141 \quad 144,1970$.

20. RESTREPO, A. - The ecology of Paracoccidioides brasiliensis: a puzzle still unsolved. J. med. vet. Mycol., 23: 323334,1985

21. RESTREPO, A.: BEDOUT, C.: CANO, L. E.: ARANGO. M. D. \& BEDOYA. V. - Recovery of Paracoccidioides hrasiliensis from a partially calcified lymph node lesion by mycroaerophilic incubation of liquid medium. Sabouraudia, 19: $295 \cdot 300,1981$

22. RESTREPO, A.; SALAZAR, M. E.; CANO, L. E. \& PATI NO, M. M. - A technique to collect and dislodge conidia produced by Paracoccidioides brasiliensis mycelial form. J. med. vet. Mycol., 24: 247 250, 1986

23. RESTREPO, B. I.: MCEWEN, J. G.: SALAZAR, M. E. \& RESTREPO. A. - Morphological development of the co nidia produced by Paracoccidioides brasiliensis mycelial form. J. med. vet. Mycol., 24: 337 -339, 1986

24. SAN BLAS. F. - Ultrastructure of spore formation in $\mathbf{P a}$ racoccidioides brasiliensis. J. med. vet. Mycol., 24 : 203210,1986

25. SZANISZLO, P. J.; JACOBS, C. W. \& GEIS, P. A. - Di morphism: morphological and biochemical aspects. In HOWARD. D. H. \& HOWARD, L. F., ed. - Fungi pathogenic for humans and animals. Part. A: Biology. New York, Marcel Dekker, 1983. p. 323436.

26. TAKEO, K. - Ultrastructure of polymorphic Mucor as observed by means of freeze-etching. III. Dormant sporan giospore. Arch. Microbiol., 99 : 99 107, 1974.

Recebido para publicaçāo em 2/11/1988. 